\title{
Short-term results of total hip replacement due to acetabular fractures
}

\author{
Asetabulum kırıklarına bağlı total kalça replasmanının kısa dönem sonuçlar \\ István Flóris, M.D., Tamás Bodzay, M.D. Ph.D., Zsolt Vendégh, M.D. Ph.D., \\ Balázs Gloviczki, M.D., Péter Balázs, M.D. \\ Péterfy Hospital and Trauma Centre, Budapest, Hungary
}

\begin{abstract}
Objectives: This study aims to evaluate short-term results of total hip replacement performed for post-traumatic osteoarthritis and/or femoral head necrosis caused by acetabular fractures.
\end{abstract}

Patients and methods: We performed 39 arthroplasties due to acetabular fractures on 25 male and 14 female patients during the course of a five-year period. The mean age of the patients was 45 years (range 25 to 73 years) at the time of surgery. Cemented cup was implanted in 29 patients and uncemented cup in 10 patients. Bone replacement was indicated in eight patients for different degrees of acetabular deformities. Implantation of an acetabular socket was indicated in six patients.

Results: The evaluation was based on the Harris hip score (HHS). The mean HHS score was 42 prior to arthroplasty and 81 after arthroplasty. Repeated surgery was required for infection in two patients. Dislocation of the prosthesis occurred in three patients, deep venous thrombosis in one patient and the lesion of the sciatic nerve in one patient after surgery.

Conclusion: Our study results suggest that the selection of the cup type depends on the condition and bone deformity secondary to acetabular fracture. Surgical interventions are technically more difficult, and take longer with a high rate of the postoperative complications and prolonged rehabilitation period, compared to arthroplasties for degenerative hip diseases.

Key words: Acetabular fracture; arthroplasty; necrosis of the femoral head; secondary post-traumatic osteoarthritis.

Acetabular fractures make up approximately $10 \%$ of all pelvic fractures. They are mainly caused by highenergy trauma (traffic accidents, falls from heights) and in many cases are associated with multi- or polytraumas, but are increasingly caused by minor trauma also. They are also frequently associated with traumatic hip joint dislocations. ${ }^{[1-3]}$
Amaç: Bu çalışmada asetabulum kırıklarına bağlı gelişen posttravmatik osteoartrit veya femur başı nekrozunda uygulanan total kalça replasmanının kısa dönem sonuçları değerlendirildi.

Hastalar ve yöntemler: Beş yıllık dönemde 25 erkek ve 14 kadın hastada asetabulum kırığına bağlı 39 artroplasti gerçekleştirildi. Hastaların ortalama yaşı, cerrahi sırasında 45 idi (dağılım, 25-73 yıl). Yirmi dokuz hastaya çimentolu komponent, 10 hastaya ise çimentosuz komponent yerleştirildi. Sekiz hastada farklı derecelerde asetabuler deformiteleri nedeniyle kemik replasmanı gerekti. Altı hastada asetabuluma soket takıld1.

Bulgular: Harris kalça skoru'na (HKS) göre değerlendirme yapıldı. Ortalama HKS skoru, artroplasti öncesinde ortalama 42; artroplasti sonrasında ise 81 idi. İki hasta enfeksiyon nedeniyle yeniden ameliyat edildi. Üç hastada protez yerinden çıktı, bir hastada derin ven trombozu gelişti ve bir hastada ameliyat sonrasında siyatik sinir lezyonu görüldü.

Sonuç: Çalışma bulgularımız, komponent tipinin seçiminin asetabulum kırığına sekonder kemik deformitesine bağlı olduğunu göstermektedir. Dejeneratif kalça hastalıklarında uygulanan artroplastilere kıyasla, cerrahi girişimler teknik olarak daha güç olmakla birlikte, daha uzun zaman alır, ameliyat sonrası komplikasyon oranı daha yüksektir ve rehabilitasyon süresi daha uzundur.

Anahtar sözcükler: Asetabulum kırı̆̆ı; artroplasti; femur başı nekrozu; sekonder posttravmatik osteoartrit.

As a consequence of acetabular fractures, three possible late post-traumatic complications potentially require reconstructive surgery: post-traumatic osteoarthritis (OA), avascular femoral head necrosis $(\mathrm{AVN})$ and heterotopic ossification (HO). According to data from the literature, the ratio of OA varies in a wide range $(5-56 \%)$, depending on fracture pattern,

- Received: March 02, 2013 Accepted: May 02, 2013

- Correspondence: István Flóris, M.D. Péterfy Hospital and Trauma Centre, H-1081 Budapest, Fiumei út 17, Hungary.

Tel: 00-36-1-2997700 Fax: 00-36-1-3338973 e-mail: floris@freemail.hu 
grade of fragment displacement and successfulness of the primary osteosynthesis; the ratio of AVN is determined at a range of $4-29 \% .{ }^{[4-6]}$ The majority of these post-traumatic deformities require hip joint arthroplasty.

Total hip arthroplasty carried out after acetabular fracture is technically demanding. The results of total hip replacement (THR) for post-traumatic OA are generally inferior to THR performed for nontraumatic arthritis. ${ }^{[7,8]}$

Frank et al. ${ }^{[9]}$ analyzed the prosthetic hip function after total hip replacement for coxarthrosis following acetabular fracture. They declared that patient age and injury severity influenced the preoperative function and hence the Harris hip score (HHS) after THR; however, these factors had no influence on the individual increase in the HHS. Most important was the preoperative HHS and the restoration of proper hip anatomy and rotational alignment.

Our aim is to evaluate the results and complications of arthroplasties performed for secondary OA and AVN after acetabular fractures.

\section{PATIENTS AND METHODS}

During a five-year period between January 2002 and December 2006, we treated in our institution 74 patients with acetabular fractures, mainly caused by high-energy trauma (64 high-energy, 10 low energy or monotrauma patients). There were 24 polytrauma patients (ISS score $>17$ ) out of 64 high-energy injuries. Other parts of the body were also injured in 40 patients (multi-trauma patients).

We analyzed the primary fracture of 39 patients (25 males, 14 females; mean age 45 years; range 25 to 73 years) according to AO/ASIF (Müller) classification, who have undergone prosthesis implantation. The type of prosthesis, with special respect to the selection of the cup and the necessity of acetabular reconstruction (grafting of the bony defect, removal of surgical implants) was also analyzed.

Thrombosis prophylaxis with low molecular weight heparin (LMWH) was applied in each patient after prosthesis implantation and patients also received non-steroid medication $(75 \mathrm{mg}$ diclofenac or indomethacinum) for at least six weeks in order to prevent heterotopic ossification.

The primary postoperative surgical complications and the functional outcome average at 31 months (range, 24-36 months) after prosthesis implantation were also investigated and compared to those prior to prosthesis implantation surgery based on the HHS.

\section{RESULTS}

Hip prosthesis implantation for post-traumatic osteoarthritis and/or femoral head necrosis was performed in $39(53 \%)$ out of 74 acetabular fractures between 6-56 months after injury.

Analysis of the primary fracture of 39 patients according to AO/ASIF (Müller) classification revealed that most of the fractures were simple. The most frequent injuries were the fractures of the posterior margin and posterior column (type $62 \mathrm{~A}$ in 20 patients, type $\mathrm{B}$ in 15 patients and type $\mathrm{C}$ in 4 patients). As a part of the primary injury, dorsal, dorso-cranial or central hip joint dislocation occurred in 22 patients.

There were simple pelvic injuries in two out of 39 patients, and the acetabular fracture was associated with AO/ASIF type $C$ pelvic ring injury also in two patients (Figure 1a-d).

Revision surgery was performed 27 months on the average (range, 6-56 months) after primary injury.

For prosthesis implantation we applied anterolateral or direct lateral approach.

Removal of all surgical implants inserted during the course of osteosynthesis was necessary in 20 out of 34 patients, and partial removal was required in two patients. Implant removal was performed simultaneous with the prosthesis implantation in 18 patients and prior to it in four patients.

During the course of revision surgeries, an uncemented cup was implanted in 10 patients, a threaded cup type Zweymüller ${ }^{\circledR}$ in six patients (Figure 2a-c) and press-fit cup type Biomet ${ }^{\circledR}$ in four patients (Figure 3a-c). A cemented cup was inserted in 29 patients (type Metrimed $^{\circledR}$ and Biomet ${ }^{\circledR}$ ).

Bone substitution was required in 10 patients due to bony defect type I-III. according to AAOS (American Academy of Orthopaedic Surgeons) classification. In two patients (AAOS type II/B) out of these 10, we implanted an uncemented cup and in another two patients we implanted a cemented cup reinforced with a titanium mesh (type I/A and II/B bony defect). Due to the extent of the bony defect, bone grafting and implantation of an acetabular socket was necessary in six patients. A Müller's socket was inserted in five patients (3 patients type I/A bony defect, 2 patients type II/A bony defect) and a socket of type Schneider-Burch in one patient (type III bony defect).

The ratio of surgical complications is demonstrated in Table I. In one out of three patients complicated with prosthesis dislocation, no further intervention 

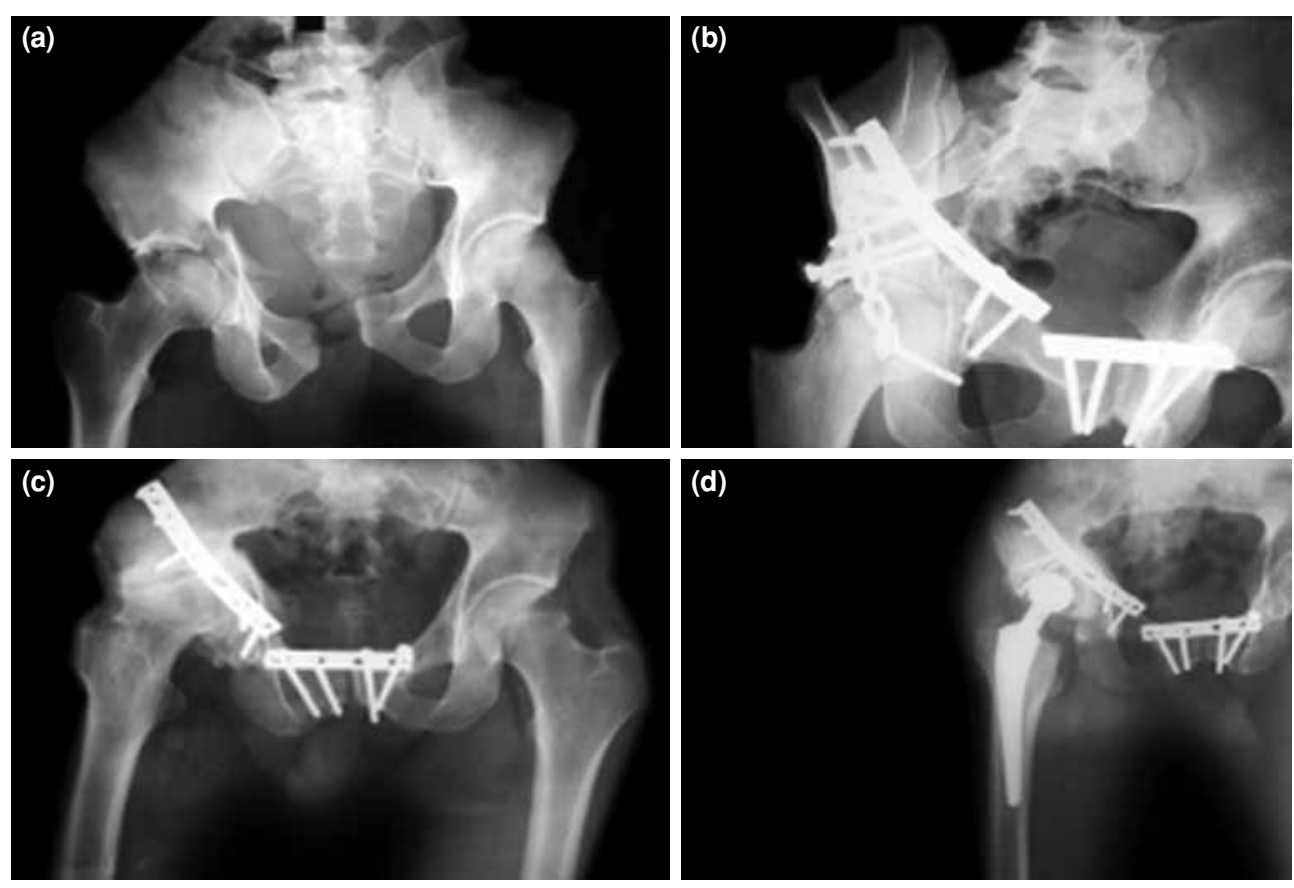

Figure 1. (a) A 38-year-old polytraumatized male patient with $\mathrm{AO}$ type $\mathrm{C} 3$ fracture, (b) the fracture was open-reduced and fixed by plates, (c) after healing of the fracture the plates were removed partially 44 months after the primary osteosynthesis (d) and cemented total hip arthroplasty were performed without bone substitution 48 months after the injury.

was required after reduction. In one patient, insertion of a dislocation preventing cup rim was required. In another patient, the cemented cup had to be revised: we inserted an acetabular socket and replaced the cup with a new one.

There were deep infections in two patients. Vacuum/ rinsing drainage and selective antibiotic therapy was applied. No prosthesis removal was necessary due to infection during the course of the investigation.
No revision surgery was necessary due to aseptic relaxation of the cup or stem in this period although the follow-up interval (48 months at the longest) was short with respect to the working life of the prosthesis.

On investigating primary postoperative surgical complications and the 31 months (range, 24-36 months) functional outcome average after prosthesis implantation according to the HHS,,$^{[10,11]}$ the preoperative
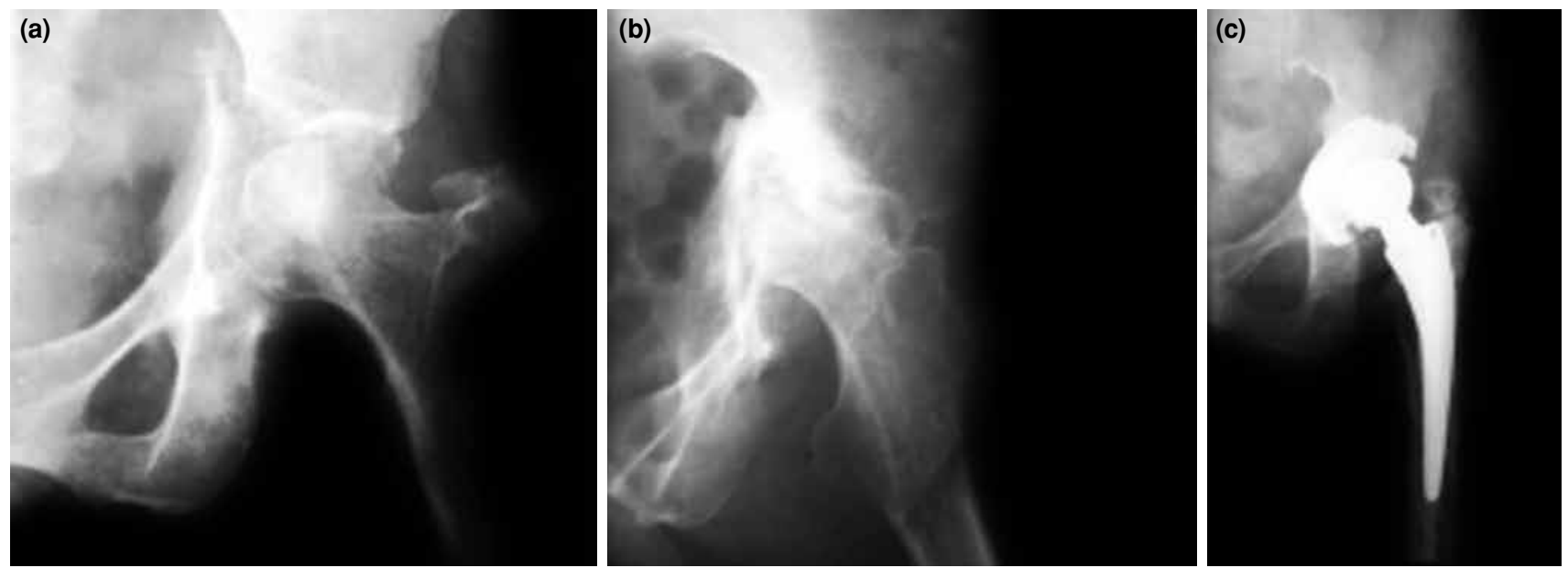

Figure 2. (a) A 56-year-old female patient with polytrauma and splenic rupture. AO type A3 fracture, (b) the fracture was treated conservatively, (c) after six months we performed cementless total arthroplasty. The centrally localized bone defect (10x25 mm in diameter) was augmented by bone autograft. 

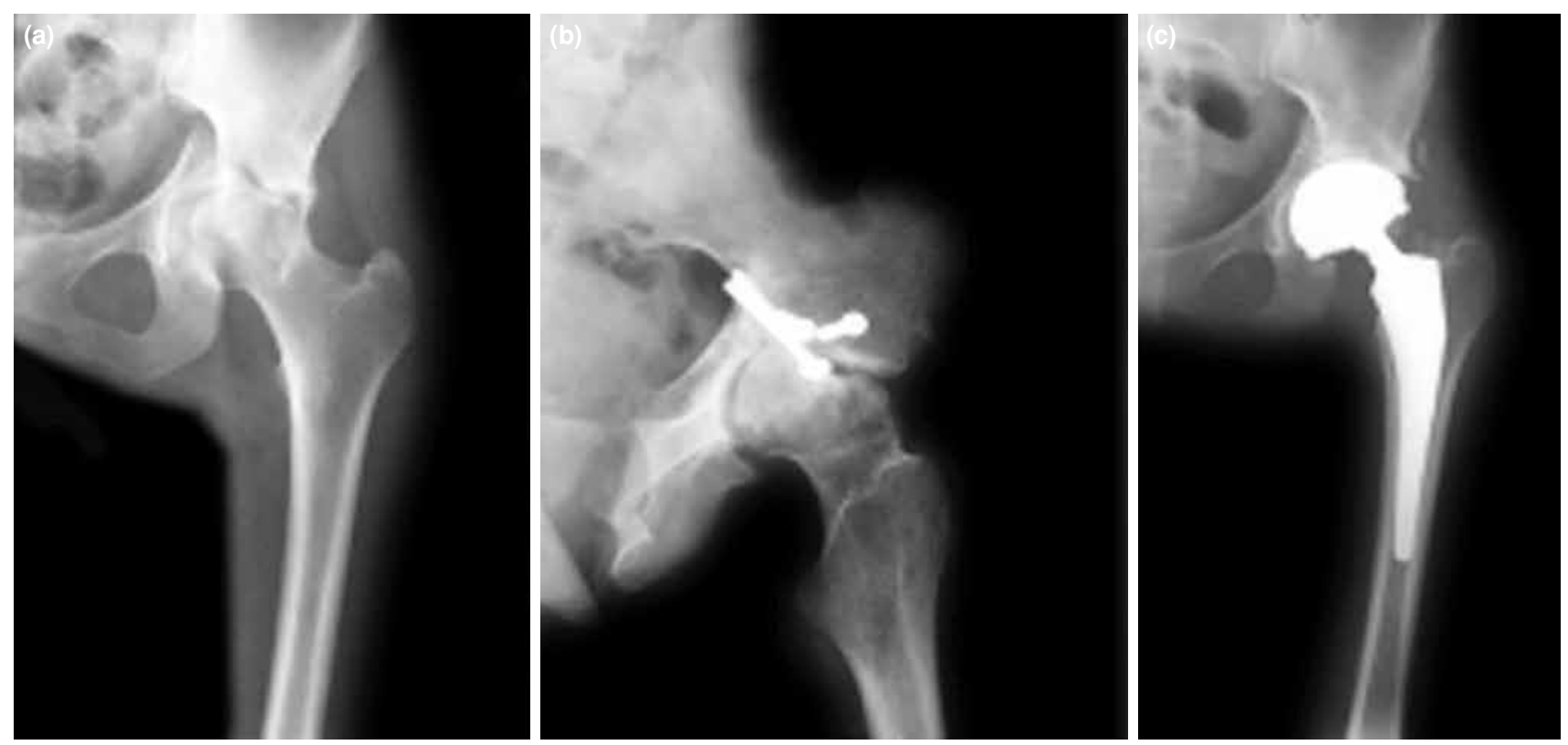

Figure 3. (a) A 25-year-old female patient with AO type B2 fracture. We performed open reduction and screw fixation. (b) After 12 months follow-up the X-ray showed necrosis of the femoral head and the dorsal acetabular rim and migration of the implants. (c) We performed cementless total hip replecement after removing the screws 14 months after injury.

HHS score was 42 (range, 16-58) on the average, which increased to 81 (range, 52-96) after surgery (Table II).

Functional outcome was worst after repeated revision surgery due to dislocation of the prosthesis where the cemented cup implanted in a surgically wrong manner had to be replaced, and implantation of an acetabular socket was also required. We observed poor functional outcome in one patient after septic complication (bone grafting, titanium mesh and cemented cup implantation was indicated due to type II/B bony defect) and in other two patients, when we implanted a cemented cup without bone grafting

TABLE

Ratio of surgical complications after hip prosthesis implantation

\begin{tabular}{lcc}
\hline Complication & \multicolumn{2}{c}{ Number of patients } \\
\cline { 2 - 3 } & $\mathrm{n}$ & $\%$ \\
\hline Postoperative hematoma without infection & 2 & 5.1 \\
$\begin{array}{l}\text { Superficial and deep infection, repeated } \\
\text { surgery, debridement }\end{array}$ & 2 & 5.1 \\
Dislocation of the prosthesis & 3 & 7.6 \\
$\quad$ Reduction, non-operative treatment & 1 & - \\
Revisional surgery, application of a & & \\
$\quad$ cup rim & 1 & - \\
$\quad$ Revisional surgery, implantation of an & & \\
$\quad$ acetabular socket & 1 & - \\
Deep venous thrombosis & 1 & 2.5 \\
Surgery-related lesion to the sciatic nerve & 1 & 2.5 \\
\hline
\end{tabular}

(HO type Brooker II) and after grafting for type I/A bony defect and implanting a Müller's socket.

Distribution of 12 patients with moderate functional outcome:

- After septic complication in one patient.

- After implantation of a cemented cup, when no bone grafting was necessary in nine patients. Prior to prosthesis implantation, stage Brooker IV HO was observed in one patient out of nine, stage III in two patients and stage II in further three patients.

- In one patient, after implantation of a Müller's socket and type I/A bony defect, and in another patient, after implantation of a Schneider-Burch socket and type III bony defect.

This list makes evident that functional outcome is influenced by numerous factors. Decreased range of motion prior to prosthesis implantation, $\mathrm{HO}$, the extent of bony defect and various possibilities for reconstruction, septic complications and surgical difficulties/failures play the most important roles.

\section{DISCUSSION}

Our aim was the evaluation of results of arthroplasties performed due to secondary OA and/or AVN. According to a few previous studies the estimated ratio of post-traumatic OA is $15-67 \%$ and that of the post-traumatic necrosis of the 
TABLE II

Functional outcome according Harris hip score after prosthesis implantation $(n=39)$

\begin{tabular}{|c|c|c|c|c|c|c|c|c|}
\hline \multirow[t]{2}{*}{ Functional outcome } & \multicolumn{2}{|c|}{$\begin{array}{c}\text { Poor } \\
H H S<70\end{array}$} & \multicolumn{2}{|c|}{$\begin{array}{l}\text { Moderate } \\
\text { HHS 70-79 }\end{array}$} & \multicolumn{2}{|c|}{$\begin{array}{c}\text { Good } \\
\text { HHS 80-89 }\end{array}$} & \multicolumn{2}{|c|}{$\begin{array}{c}\text { Excellent } \\
\text { HHS }>90\end{array}$} \\
\hline & $\mathrm{n}$ & $\%$ & $\mathrm{n}$ & $\%$ & $\mathrm{n}$ & $\%$ & $\mathrm{n}$ & $\%$ \\
\hline No of patients & 4 & 10 & 12 & 31 & 10 & 26 & 13 & 33 \\
\hline
\end{tabular}

HHS: Harris hip score.

femoral head is $15-20 \%$ although they frequently occur combined. ${ }^{[12-16]}$ This ratio correlates with our experiences $(53 \%)$.

The reason for late femoral head necrosis is the traumatic dislocation of the hip joint compromising the blood supply to the femoral head (immediate reduction is absolutely indicated even in polytrauma or severely injured patients!). Secondary OA may be caused by incongruent joint surfaces, direct lesions to the cartilage of the femoral head and/or acetabular joint surface, intraarticular bony fragment, surgical implants in the joint causing secondary damage to the cartilage and avascular necrosis of the femoral head.

The literature is not consistent in terms of the cup to be implanted for the secondary hip joint osteoarthritis caused by acetabular fractures. Both non-cemented (threaded and press-fit) cups and cemented cups are used.

Ranawat et al. ${ }^{[15]}$ reported 32 post-traumatic hip prosthesis implantations where they achieved better results with uncemented prostheses, however these results are still not as good as those after prosthesis implantations performed for primary osteoarthritis.

Weber et al. ${ }^{[16]}$ reported 66 cases where they implanted a cemented cup in 44 cases and an uncemented cup in 20 cases. A hybrid prosthesis was implanted in two patients (uncemented stem, cemented cup). A longer prostheses lifetime was observed after implantation of the uncemented cup, but the authors remarked that implantation of a cemented cup was required in 17 cases due to the extent of acetabular bony defects, which alone increases the ratio of complications.

Bellabarba et al. ${ }^{[17]}$ reported 40 cases where a noncemented prosthesis was implanted after acetabular fractures; the outcome was almost the same as that after surgeries performed for degenerative diseases. At the same time, they compared previous nonoperatively- and operatively-treated cohorts, and confirmed that bone grafting was more frequently necessary in the operatively-treated group.
Zhang et al. ${ }^{[8]}$ reported 55 patients where they used a cementless cup in 47 . They concluded that total hip arthroplasty for failed treatments of acetabular fractures can be technically challenging. The complication rate is significantly higher than that reported for patients with nontraumatic osteoarthritis. They demonstrated that THR for failed treatment of acetabular fractures provides excellent results whether with cemented or cementless components.

Huo et al. ${ }^{[18]}$ reported 21 cases of implanting exclusively non-cemented cups for the treatment of acetabular fractures via prosthesis implantation.

On the other hand, the literature is consistent in terms of selection of the cup mainly depending on acetabular deformity, extent of acetabular bony defect and pseudoarthrosis.

In order to pre-plan the reconstructive surgery, it is essential to determine the extent of the bony defect and/or of the pseudoarthrosis. Preoperative planning can be performed well based on two dimensional (2D) or 3D CT-scans. A disadvantage of this method is that it may not be always be informative enough, due to metal implants in the scanned slices. In such cases we use special, oblique $\mathrm{X}$-ray projections (ala, obturator) and inlet-outlet projections (Judet-Letournel), which may provide useful information about the status of the acetabular margin and bottom. The preoperative assessment of the patient comprises the following examinations: determination of possible deformities of the ipsilateral and contralateral lower limb, measuring the difference between the length of the limbs, assessing the soft tissue condition and excluding any possible infection (clinical and radiological signs, sedimentation rate, C-reactive protein, procalcitonin and laboratory investigations). In case of suspected occult infection (elevated inflammatory biochemical parameters), scintigraphy performed with gallium citrate GA-67 and/or with technetium-99 m (99mTc) LeukoScan ${ }^{\circledR}$ may support the diagnosis and localize the infection site. In case of suspected infection, bacteriological investigation of the joint punctuate is recommended. 
The following aspects must be taken into consideration during the course of preoperative planning:

1. Healing of the previous fracture/ pseudoarthrosis

2. Fracture localization (anterior, posterior column, bottom of the cup or combined)

3. Localization and extent of the acetabular bony defect

4. Necessity of bone grafting

5. Patient's age, bone quality

6. Extent of heterotopic ossification according to Brooker's classification

\section{Exclusion of an occult infection}

Acetabular bony defects are classified according to AAOS, Paprosky and Gross's classification. ${ }^{[19,20]}$ This is not completely usable in case of bony defects arising after acetabular fractures, because the bony defect is often combined with an unhealed fracture, pseudoarthrosis, especially after non-operative treatment or primary osteosynthesis performed for fractures of the dorsal wall and dorsal column.

Mears and Velyvis ${ }^{[2]]}$ recommend a classification for acetabular bony defects arising after fractures, which also provides therapeutically important considerations. According to this clinical classification, acetabular bony defects smaller than $10 \mathrm{~mm}$ in diameter are of only minor structural importance and usually no bone grafting is required. Bony defects with 10-25 $\mathrm{mm}$ in diameter are of moderate importance; defects larger than $25 \mathrm{~mm}$ in diameter are relevant and of very high surgical importance. Naturally, localization of the bony defect (acetabular margin or central part) makes a great difference and essentially determines the selection of the cup to be implanted.

Clinical determination of the extent of the pseudoarthrosis is similar to the classification of the extent of the acetabular bony defect. Pseudoarthrosis is frequently seen after fractures of the dorsal wall or dorsal column, and less frequently after transverse fractures and fractures of the anterior column. In case of acetabular bony defects smaller than $10 \mathrm{~mm}$ in diameter, bone grafting with bone chips is usually sufficient. In case of acetabular bony defects $10-25 \mathrm{~mm}$ in diameter, provident resection of the pseudoarthrosis and autologous bone grafting is required, which has to be protected with a titanium mesh prior to implantation of the cup. In case of an articular step-off larger than $25 \mathrm{~mm}$ in diameter, an acetabular socket has to be implanted after bone grafting. Alternatively, in case of a pseudoarthrosis arising after plate osteosynthesis performed through dorsal approach, open reduction of the fragments and transplantation of cancellous bone chips or bone block and internal fixation is required.

Opinions are not uniform in terms of primary treatment of acetabular fractures: primary osteosynthesis or arthroplasty are similarly preferred. Both procedures have advantages and disadvantages as well. Primary arthroplasty (few days after injury) is recommended only in well selected cases, mainly in case of monotrauma in the elderly with osteoporotic bones, or for acetabular fractures combined with femoral head or neck fracture (type Pipkin IV femoral head fracture) and in case of extensive damage to the acetabular cartilage or pathological fractures. ${ }^{[2,21,22]}$ Boraiah et al. ${ }^{[23]}$ and Saxer et al. ${ }^{[2]}$ described a new surgical procedure in geriatric patients wherein they combined open reduction and internal fixation with a primary THR. ${ }^{[23,24]}$

Mears and Velyvis ${ }^{[22]}$ reported on 63 out of 789 patients with acetabular fractures who underwent primary arthroplasty based on the above enrollment criteria within six days after injury, with good functional outcome [HHS: excellent in 58 cases (33\%), good in 21 cases (12\%), moderate in 16 cases (9\%) and poor in 5 cases $(3 \%)$ ].

Belated, delayed arthroplasty, acetabular bony defect (OA and/or AVN arisen after nonoperative treatment), joint surface incongruence after intraarticular fractures, pseudoarthrosis, delayed bone healing, central, cranial dislocation or subluxation of the femoral head and muscle atrophy may make surgery more difficult. Also, extensive scarring after osteosynthesis, $\mathrm{HO}$, implants hindering the reconstruction of the acetabulum and implantation of the cup, previous surgical scars, bad soft tissue conditions and occult infections may occur. When indicating a prosthesis implantation, we have to take into consideration that predominantly young people are injured.

In case of injuries caused by high-energy trauma (making up the majority of acetabular fractures in young, multi- or polytrauma patients), we follow the applicable trauma protocol and the appropriate diagnostic and therapeutic algorithm. Hip joint dislocation requires urgent reduction; internal fracture fixation is performed after the secondary diagnostic steps, 3-5 days after injury. The aim of osteosynthesis is the reconstruction of the joint surface congruence. Because the ratio of post-traumatic OA and/or AVN is above $50 \%$ 
TABLE III

Recommendations for bone substitution of acetabular bony defects and selection of cup to be inserted after acetabular fractures, in patient of a hip arthroplasty

\begin{tabular}{ll}
\hline Type of defect & Treatment \\
\hline Central, cavital defect $(<10 \mathrm{~mm} \varnothing)$ & $\begin{array}{l}\text { Substitution with cancellous bone chips harvested from the femoral head, } \\
\text { uncemented, threaded or cemented cup } \\
\text { Substitution with cancellous bone chips harvested from the femoral head, } \\
\text { uncemented, press-fit or cemented cup }\end{array}$ \\
Central, medial defect $(10-25 \mathrm{~mm} \varnothing)$ & $\begin{array}{l}\text { Substitution with cancellous bone chips harvested from the femoral head, titanium } \\
\text { mesh, uncemented, threaded or cemented cup }\end{array}$ \\
Central, medial defect $(>25 \mathrm{~mm} \varnothing)$ & $\begin{array}{l}\text { Bone substitution with cortico-cancellous graft or cancellous bone chips, Müller's } \\
\text { socket, cemented cup } \\
\text { Bone substitution with cortico-cancellous graft, Müller's socket, cemented cup or } \\
\text { dorsal plate osteosynthesis, cemented cup }\end{array}$ \\
Borsal wall or column defect $(>25 \mathrm{~mm} \varnothing)$ & $\begin{array}{l}\text { Bone substitution with cortico-cancellous graft or cancellous bone chips, } \\
\text { pseudoarthrosis after transverse or }\end{array}$ \\
T-shaped fractures &
\end{tabular}

after acetabular fractures, creating ideal conditions for a later arthroplasty is an additional aim of the osteosynthesis. This means that in case of development of post-traumatic osteoarthritis indicating prosthesis implantation, neither bone healing disorder, nor pseudoarthrosis or any bony defect should be present on the central or peripheral part of the acetabulum. In general, in case of predominantly young patients, uncemented cup implantation is recommended. If there is no bony defect or pseudoarthrosis and bone quality is good, an acetabulum with satisfactory blood supply can be configured and an uncemented, press-fit cup can be inserted. This can be performed usually in case of osteoarthritis secondary to post-traumatic femoral head necrosis. An uncemented, threaded cup can be implanted after grafting the bony defect with autologous cancellous bone, provided the circumference of the acetabular margin is intact. In case of poor bone quality, sclerotic bottom of the acetabulum, or bony defect larger than $10 \mathrm{~mm}$ in diameter, implantation of a cemented cup is supplemented (as occasion requires) with a titanium mesh and acetabular socket.

After fracture of the anterior, posterior wall and column, combined injuries or transverse fractures in the upper third complicated with central or dorsal dislocation of the femoral head, the presence of a larger or smaller bony defect or pseudoarthrosis has to be taken into consideration, even after osteosynthesis is performed in an appropriate manner. Selection of the cup type and necessity of bone grafting depend on the extent and localization of the acetabular bony defect and pseudoarthrosis (Table III). For bone substitution we predominantly use autografts; bone, harvested from the resected femoral head and trochanteric region is beneficially usable as bone blocks on cancellous bone chips. In case of extended bony defects allografts are also usable. Combination of autologous bone grafts with an allograft is a widely applied process predominantly in reconstructive spine surgery in those cases where voluminous bone grafting is required. ${ }^{[25]}$

In our everyday practice, the first choice process is grafting with autologous bone, but in case of extended bony defects we use the combined method as well. The grist for bone substitution is composed of autologous graft and deep frozen allograft.

Another important question is the timing of the prosthesis implantation. If prosthesis implantation is indicated for post-traumatic OA or AVN, it should preferably be performed when the acetabular fracture is completely healed and the prosthesis can be implanted into stable bony bedding. The bony consolidation after acetabular fractures takes 6-12 months. Timing of surgery may naturally be influenced by delayed bone healing, development of a pseudoarthrosis, migration of previously inserted surgical implants, $\mathrm{HO}$, condition of the soft tissues, larvate or acute infection and other factors originating from the patient's age and concomitant diseases.

In case of post-traumatic disorders following acetabular fractures, indicating any kind of surgery requires extensive experience; the process and type 
of reconstructive surgery has to be determined individually in a differentiated manner. Precise preoperative diagnostics and planning of surgery (series of surgeries) are extremely important. Implantation of a prosthesis is a great challenge even for an experienced orthopaedic-trauma surgeon. We must not forget about the detailed information given to the patient, because these kinds of surgical interventions usually result in higher rates of complications and more modest functional outcomes, when compared to arthroplasties performed for degenerative hip diseases.

\section{Declaration of conflicting interests}

The authors declared no conflicts of interest with respect to the authorship and/or publication of this article.

\section{Funding}

The authors received no financial support for the research and/or authorship of this article.

\section{REFERENCES}

1. Harvie P, Chesser TJ, Ward AJ. The Bristol regional pelvic and acetabular fracture service: workload implications of managing the polytraumatised patient. Injury 2008;39:83943. doi: 10.1016/j.injury.2008.01.001.

2. Helfet DL, Borrelli J Jr, DiPasquale T, Sanders R. Stabilization of acetabular fractures in elderly patients. J Bone Joint Surg Am 1992;74:753-65.

3. Pagenkopf E, Grose A, Partal G, Helfet DL. Acetabular fractures in the elderly: treatment recommendations. HSS J 2006;2:161-71. doi: 10.1007/s11420-006-9010-7.

4. Giannoudis PV, Grotz MR, Papakostidis C, Dinopoulos H. Operative treatment of displaced fractures of the acetabulum. A meta-analysis. J Bone Joint Surg [Br] 2005;87:2-9.

5. Sermon A, Broos P, Vanderschot P. Total hip replacement for acetabular fractures. Results in 121 patients operated between 1983 and 2003. Injury 2008;39:914-21. doi: 10.1016/j. injury.2007.12.004.

6. Weber M, Berry DJ, Harmsen WS. Total hip arthroplasty after operative treatment of an acetabular fracture. J Bone Joint Surg [Am] 1998;80:1295-305.

7. Pavelka T, Linhart M, Houcek P. Hip joint arthroplasty following surgical treatment of acetabular fracture. Acta Chir Orthop Traumatol Cech 2006;73:268-74. [Abstract]

8. Zhang L, Zhou Y, Li Y, Xu H, Guo X, Zhou Y. Total hip arthroplasty for failed treatment of acetabular fractures: a 5-year follow-up study. J Arthroplasty 2011;26:1189-93. doi: 10.1016/j.arth.2011.02.024.

9. Frank C, Siozos P, Wentzensen A, Schulte-Bockholt D, Grützner PA, Gühring T. Total hip replacement for coxarthrosis following acetabular fracture. Significance of age and injury severity. Unfallchirurg 2010;113:1013-8, 10202. doi: 10.1007/s00113-010-1826-4. [Abstract]

10. Harris WH, Crothers O, Oh I. Total hip replacement and femoral-head bone-grafting for severe acetabular deficiency in adults. J Bone Joint Surg [Am] 1977;59:752-9.

11. Harris WH. Traumatic arthritis of the hip after dislocation and acetabular fractures: treatment by mold arthroplasty. An end-result study using a new method of result evaluation. J Bone Joint Surg [Am] 1969;51:737-55.

12. Mears DC, Velyvis JH, Chang CP. Displaced acetabular fractures managed operatively: indicators of outcome. Clin Orthop Relat Res 2003;173-86.

13. Moed BR, Yu PH, Gruson KI. Functional outcomes of acetabular fractures. J Bone Joint Surg [Am] 2003;85-A:1879-83.

14. Moed BR, WillsonCarr SE, Watson JT. Results of operative treatment of fractures of the posterior wall of the acetabulum. J Bone Joint Surg [Am] 2002 ;84-A:752-8.

15. Ranawat A, Zelken J, Helfet D, Buly R. Total hip arthroplasty for posttraumatic arthritis after acetabular fracture. J Arthroplasty 2009;24:759-67. doi: 10.1016/j.arth.2008.04.004.

16. Weber M, Berry DJ, Harmsen WS. Total hip arthroplasty after operative treatment of an acetabular fracture. J Bone Joint Surg [Am] 1998;80:1295-305.

17. Bellabarba C, Berger RA, Bentley CD, Quigley LR, Jacobs JJ, Rosenberg AG, et al. Cementless acetabular reconstruction after acetabular fracture. J Bone Joint Surg [Am] 2001;83A:868-76.

18. Huo MH, Solberg BD, Zatorski LE, Keggi KJ. Total hip replacements done without cement after acetabular fractures: a 4- to 8-year follow-up study. J Arthroplasty 1999;14:827-31.

19. Choplin RH, Henley CN, Edds EM, Capello W, Rankin JL, Buckwalter KA. Total hip arthroplasty in patients with bone deficiency of the acetabulum. Radiographics 2008;28:771-86. doi: 10.1148/rg.283075085.

20. Gross AE, Allan DG, Catre M, Garbuz DS, Stockley I. Bone grafts in hip replacement surgery. The pelvic side. Orthop Clin North Am 1993;24:679-95.

21. Mears DC, Velyvis JH. Primary total hip arthroplasty after acetabular fracture. Instr Course Lect 2001;50:335-54.

22. Mears DC, Velyvis JH. Acute total hip arthroplasty for selected displaced acetabular fractures: two to twelve-year results. J Bone Joint Surg [Am] 2002;84-A:1-9.

23. Boraiah S, Ragsdale M, Achor T, Zelicof S, Asprinio DE. Open reduction internal fixation and primary total hip arthroplasty of selected acetabular fractures. J Orthop Trauma 2009;23:243-8. doi: 10.1097/BOT.0b013e3181923fb8.

24. Saxer F, Studer P, Jakob M. Open stabilization and primary hip arthroplasty in geriatric patients with acetabular fractures: combination of minimally invasive techniques. Unfallchirurg 2011;114:1122-7. doi: 10.1007/s00113-011-20640. [Abstract]

25. Schachar N, Fennel C, Otsuke T, Ladd A. Bone graft and bone substitutes. In: Robert HF, Herbert K, Arthur LM, Herbert K, Arthur M, editors. Orthopaedics. Philadelphia: Mosby; 2002. p. 186-94. 